\title{
TCOM \\ Bringing back the debate on mediated and unmediated science communication: the public's perspective
}

\section{Ana Delicado, Jussara Rowland and João Estevens}

\begin{abstract}
When analysing the actors of the science communication ecosystem, scholarly research has focused on the perceptions and attitudes of scientists, science journalists, and science communicators. How the public envisages the roles of science producers and mediators is mostly uncharted territory. We address this gap, by examining the results of a public consultation in Portugal concerning science communication. We show that the public demonstrates a clear preference for science communication performed by scientists, over journalists, although credibility and trust depend on multiple factors. We also ascertain that professional science communicators are mostly invisible, though the public recognises the value of 'translators'.
\end{abstract}

Keywords

DOI

Introduction
Professionalism, professional development and training in science communication; Public engagement with science and technology; Science and media

https://doi.org/10.22323/2.20030210

Submitted: 16th November 2020

Accepted: 30th March 2021

Published: 10th May 2021

A classic discussion in science communication studies has to do with who should play a primary role in the field: scientists who produce the science or communicators who translate it to the public. It is a well-known narrative that as science became an increasingly specialised endeavour, scientists drew back from communicating their results to other than their peers and new occupations emerged: science journalists, museum curators, event organisers, facilitators, Public Relations in research institutions, etc. [Dunwoody, 2014].

There is a wealth of studies on how scientists see their role in science communication [see, for instance, Poliakoff and Webb, 2007; Nielsen, Kjaer and Dahlgaard, 2007; or Dudo and Besley, 2016] and how they assess the work done by these 'new' mediators [e.g. Gascoigne and Metcalfe, 1997; Peters et al., 2008]. There is also abundant research on what mediators do and think about themselves and about the other actors of the science communication ecosystem [for instance, 
Nielsen, 2010; Jensen and Holliman, 2016; or Riesch, Potter and Davies, 2016]. What is far less common are studies on how the audiences perceive the actors of science communication.

This article aims to address this gap, by exploring the preferences of citizens regarding unmediated or mediated science communication, that is to say, which roles are ascribed to scientists and to communicators (journalists and science communicators). The article is based on information collected through a public consultation about science communication.

The article begins with a brief overview of the literature around this topic and the absences in this literature. This is followed by a short methodological explanation. The results section is divided into the discourses of citizens about scientists and about mediators. A summary conclusion is at the end.

Framework

The theoretical discussion between unmediated and mediated science communication is becoming more multifaceted. The 'science communication ecosystem' [Ridgway et al., 2019] is becoming an increasingly complex area of activity, with a multitude of actors at play: 'visible scientists, science communicators, science journalists, popular science writers, museum curators and interpreters, press office and public relations professionals, and others' [Bauer and Jensen, 2011, p. 3]. Bucchi [2008] attributes this diversity, and in particular the emergence of professional mediators between science and the public, to the growing complexity of science and the need for 'translation', as well as the professional interests of two of these actors, scientists and mediators.

After a multitude of historical studies that showed how scientists retreated from science communication to focus on science production and communication with their peers, in the early 2000s it became relevant again to analyse how scientists engage with their publics. In the U.K., in 2000 the Welcome Trust conducted a survey on the "Role of Scientists in Public Debate", which conclude than more than half took part in science communication activities and 56\% wanted to spend more time doing it [Poliakoff and Webb, 2007]. Six years later the Royal Society carried out a "Survey of Factors Affecting Science Communication by Scientists and Engineers", in which almost two thirds of respondents stated that the time demands of research constituted a barrier to public engagement [Poliakoff and Webb, 2007]. Similar work was developed in other countries, for instance Nielsen, Kjaer and Dahlgaard [2007] carried out a survey of Danish scientists about science communication practices and representations in which the authors ascertain that scientists are keen to participate more in science engagement activities and believe that these activities should receive more public funding. With a different methodological strategy, Davies [2008] analysed group discussions of scientists to ascertain how they talk about talking to the public, in particular their ideas on public communication on their research and the purposes of science communication. She found that one-way communication with the public is still the dominant framework and at the same time seen as difficult and dangerous (in terms of balancing entertainment and truth), although she has also encountered diverse and flexible understandings of public engagement. 
Another line of studies concerns the gender differences in public engagement practices. For instance, Crettaz von Roten [2011] found that male and female scientists express the same attitudes towards public engagement, but male scientific perform engagement activities more often than female scientists, which is in part due to the fact that media tend to contact male scientists more often.

Horst [2013], following an approach from organisational communication, conducted interviews with Danish scientists about their role in science communication, ascertaining that it is closely connected with their perceptions of identity and organisational culture and that they see themselves as 'representing science as both "speaking on behalf of" science and symbolically "standing for" science and its organizations'. Concomitantly, based on an online survey of sample of members of the American Association for the Advancement of Science (AAAS), Dudo and Besley [2016] conclude that scientist 'most prioritize communication designed to defend science from misinformation and educate the public about science, and least prioritize communication that seeks to build trust and establish resonance with the public' [Dudo and Besley, 2016, p. 1].

Several studies addressed the motivations and barriers of scientists who participate in specific outreach programmes. Martín-Sempere, Garzón-García and Rey-Rocha [2008] surveyed scientists who participated at the Madrid Science Fair and concluded that they were mostly motivated by the wish to increase public interest in and enthusiasm for science, scientific culture, and awareness and appreciation of science and scientists. Mizumachi et al. [2011] interviewed early-career scientists who had participated in science cafes in Japan but the authors focused on the factors that motivate a reluctance to participate: the perception that the activity is time-consuming, outside their scope of work, without any benefit, and generates feelings of uneasiness in the dialogue with the public. Conversely, Cerrato et al.'s [2018] focus groups conducted with the young scientists who volunteered in the Children's University programme in Italy uncovered strong motivations to participate, namely the desire to improve their communication skills and a sense of duty towards the public.

Scientists have also often been queried about their relationship with the media. One such example was Gascoigne and Metcalfe's [1997] survey of Australian scientists about communicating through the media, which identified a group of 'experienced media users' who saw the advantages of reaching audiences through media and were willing to tolerate media's excesses and omissions, and a group of scientists with little or no media experience who distrusted media and do not see collaborations as being part of their job. Hans Peter Peters [et al. 2008; 2013] has worked on the perceptions of scientists about science journalism and ascertained that interactions between scientists and journalists are less conflictual than expected and that scientists have a mostly positive perception of them, although maintaining some concerns (being misquoted, feeling lack of control). Peters [2014] has also examined the role of scientists as public experts, particular sought after by the media, but in danger of losing credibility by going over the limit of their expertise.

Several studies [Dunwoody, 2014; Besley and Tanner, 2011; Trench and Miller, 2012; Baram-Tsabari and Lewenstein, 2017] show that scientists should receive training on how to talk with journalists, how to perform science communication activities, and how to collaborate with professional science communicators. 
In what regards mediated science communication, by far the most studied mediators are science journalists. Dunwoody [2014] offers an overview of science journalism, that covers both how science is portrayed in the media and the challenges that science journalism currently faces, in particular due to the rise of digital technologies. She addresses issues such as how science journalism falls in contradiction with scientific practice (short topic stories to cover long drawn out research endeavours), how balanced journalism can give the floor to minority-held opinions and controversies, and how scientists and journalists disagree about accuracy.

There are several analyses on how science journalism is under threat from the decline of traditional media and the rise of digital media. Pinholster and O'Malley [2006] in a survey of science journalists found that they feel concerned with the crisis of printer media and under pressure to deliver breaking news and finding researchers to comment, as well as visual support for the news. Dunwoody [2014] describes how journalists are under pressure to deliver news faster, to cater for the public's demands, to search for multiple sources to verify information. Granado [2011] carried out a survey of European science journalists that focused on their use of the internet to search for information, leading to an emphasis on breaking stories rather than long term reporting and feature stories, and thus to loss of information diversity. Bauer, Howard et al. [2013] surveyed science journalists across the world to assess how the working conditions of journalists have changed in view of the crisis of printed media and the increasing commercialisation of science.

Again, the issue of training arises in the literature: science training for journalists is an often proposed solution to the perceived lack of competence of journalists in covering science stories [Dunwoody, 2004; Dunwoody, 2014].

Since research centres, science museums, and even specialised private companies increasingly need full-time human resources devoted to public engagement activities [Bauer and Jensen, 2011; Neresini and Bucchi, 2011], there is a growing body of studies on types of mediators other than science journalists.

These studies can be grouped in four categories:

- surveys of research centres to assess public engagement practices, as well as material and human resources devoted to them; for instance, Neresini and Bucchi's [2011] survey of 40 European research institutions or Entradas and Bauer's [2017] survey of research institutes in Portugal;

- surveys of professional science communicators regarding their sociodemographic profiles, motivations and attitudes towards public engagement - see, for, instance, Nielsen [2010] on science communicators in Denmark, who ascertained that they are mostly motivated to contribute to democratic debate and social legitimisation of science and technology, of which they have a predominantly constructivist view; Jensen and Holliman [2016] on science communicators in the U.K. about the shift to deficit to engagement model or Riesch, Potter and Davies [2016] on science communicators involved in the Open Air Laboratories project; or Pinto, Costa and Cabral [2017] on science communicators in the marine sciences to examine their perceptions of the scientists and the audiences they work for. 
AbiGhannam [2016] focused on women science communicators and, based on discourse analysis, identified four types of communicator:

Expressive/Escapist, Advocate/Normaliser, Edutainer, and Performer/Sharer;

- studies on the development and institutionalisation of science communication as a profession within particular national contexts, such as Australia [Gascoigne and Metcalfe, 2017] or Mexico [Sánchez-Mora et al., 2015];

- studies on the graduate training of professional science communicators [Longnecker and Gondwe, 2014; Trench, 2017a; Gascoigne and Metcalfe, 2017].

However, for Trench [2017b], science communication as a profession is still on the initial rungs of the ladder of professionalisation and has yet to meet much of the defining characteristics of being a profession (a classical topic in the sociology of professions).

In short, the actors of the science communication ecosystem, in particular scientists and mediators (journalists and communicators), have been the subject of intensive research, in particular about how they see their own and the other's roles in science communication and the barriers and opportunities for science communication in each group.

Far less frequent are studies about how the public sees the actors of science communication. Public opinion surveys on science may include questions on representations of and trust in scientists or, less frequently, in journalists, but perceptions of their role in science communication (other than more general assessments of science in media) are almost entirely absent.

This article seeks to address this gap in the literature, by examining how the public envisions scientists and mediators in science communication. It is focused on the case of Portugal, a country classified in the group of 'consolidated countries' of science communication culture in the study of Mejlgaard et al. [2012].

\section{Methodology}

This article is based on the work carried out for the project CONCISE Communication role on perception and beliefs of EU Citizens about Science, ${ }^{1}$ whose main objective is to learn the role science communication plays on the origin of beliefs, perceptions and knowledge concerning scientific issues. The core method that underpins the CONCISE project is public consultations with citizens in each participating country.

This article focusses on an emerging topic identified during the analysis of the Portuguese corpus and it is based exclusively on the results achieved in Portugal. The public consultation in Lisbon took place in November 2019 and gathered together 102 residents in Portugal. We strived to achieve not representativeness in

\footnotetext{
${ }^{1} \mathrm{~A}$ research and innovation project funded by the European Commission under the programme Horizon 2020 (GA n. 824537). The project is coordinated by the University of Valencia (Spain) and the consortium includes eight other partners from five countries (Italy, Portugal, Spain, Slovakia and Poland).
} 
the sample but rather diversity and inclusion of different points of view. The sample was skewed in terms of gender ( $67 \%$ of were women) and education (68\% had a university degree) but fairly diverse in terms of age ( $27 \%$ under 35 years, 31\% between 35 and 49 years, $28 \%$ between 50 and 64 and 13\% over 65 ), occupation, and regional provenance $(60 \%$ from outside the Lisbon Metropolitan Area).

Citizens were recruited through traditional and social media, institutional mailing lists, posters and leaflets, and targeted email campaigns. Participants in the consultation were divided in groups, sitting at tables of seven to nine persons each, together with a moderator and an observer. The consultation lasted the whole day.

Four specific scientific topics (climate change, GMO, vaccines and complementary medicine) were discussed following a similar script, agreed to by all national teams that addressed three main research questions: 1) How are citizens informed? Which channels are preferred to access information? 2) How do citizens rate channels and sources of information in terms of reliability? 3) What do citizens propose to improve scientific communication?

The discussions were entirely tape-recorded and fully transcribed. The transcriptions were subjected to qualitative content analysis through NVivo coding by all CONCISE teams using a common codebook with a tree structure articulated around the three main sections of the discussions. For this article the Portuguese team further developed this analysis, focusing on the actors of science communication. All references related to these actors were considered and recoded into a new tree structure that allowed us to identify some prior themes. From there codes were grouped together in order to identify clusters and prioritise main themes [King and Brooks, 2018]. All three team members of the Portuguese team were involved in this process and agreed in the final thematic structure. This article is based on this thematic analysis and citations from participants are illustrative of the diversity of opinions expressed. No quantitative information is given on how many people expressed the opinions because discussions evolved in different ways in each table.

This article is focused on how participants talked about two main actors of science communication: scientists and mediators (journalists and professional science communicators). It examines who the public thinks should do science communication, why some actors are considered as more relevant than others, what are the advantages and drawbacks of each actor and what kinds of communication should be done.

Scientists

Contrary to other countries in Europe, historically surveys on public understanding of science have shown that there are high levels of trust in science and in scientists in Portugal. For instance, in the 2018 Wellcome Global Monitor 34\% of respondents in Portugal have high trust in science (the global average is $18 \%$ ) and $70 \%$ believe that science benefits people like them. Portugal has had a veritable science communication boom in recent years and scientists have very much been a part of this. Most of the activities of the Ciência Viva Agency, the national agency for promoting science dissemination created in 1996 under the aegis of the Ministry for Science (currently an association, but still with strong ties to the public sector), have 
relied on unpaid work by researchers: lectures, open days, field visits in summer, internships in research institutions, to mention but a few. The law that governs publicly funded research centres demands that dissemination be part of their regular activities (Decree-Law n. 125/99 and Decree-Law 163/19, Entradas, Junqueira and Pinto [2020]) and project funding is also increasingly dependent on combining research and dissemination activities. Furthermore, the media tends to have a quite respectful relationship with scientists [Carvalho and Pereira, 2008] and scientists are often invited to participate in TV news broadcasts and programmes.

It is thus unsurprising that the results of the consultation show that scientists are by far the actors in science communication most favoured by the public. Citizens place value in unmediated science communication, that is to say scientists talking about their own work. Some are able to name a few scientists that they see as being both leaders in their areas and good communicators (most men, but a few women as well).

Scientists and their institutions (universities, research centres) are very often seen as a guarantee of credibility. The credibility of scientists can vary according to citizens' criteria such as host institutions (with the customary mistrust of companies), scientific area, publication track record, and unanimity among scientists
Also, the scientific area. I think it is very important. To have proof... (...) of those who study. I care a lot about the scientific area. (Rodrigo, age 45-54, secondary education)

Unlike the concerns science communicators sometimes express, it is curious to note that controversies and disagreement among scientists are not always seen as a threat to their credibility
We speak here in credible scientists, we all speak, but it is also very important not to forget that there are many credible scientists who are on opposite sides, have worked on opposite sides, have different opinions and all of them are credible too and therefore... They all have fantastic scientific arguments, they all have... they are able to explain and justify the opposite in an absolutely wow way. Not least because it is part of their role as scientists, is it not? (Júlia, age 45-54, university education)

Some participants see science communication by scientists as a material or a moral obligation, something they should do as part of their job

\section{In addition to the ethical responsibility of the media I also think it is the ethical responsibility of the academy, of scientists, of science communicators impose themselves on the media. (Cristina, age over 65, university education)}

However, it should be noted that no participants mentioned social media as a channel to fulfil this responsibility. No one stated that they followed any scientist on Facebook or Twitter or even the institutional accounts of universities and research centres. It begs to consider just how effective institutional science communication in online social networks really is.

Also, a few of the participants were aware that scientists can be criticised and devalued by participating in science communication 
Maybe, sometimes, here regarding communication in science, I think that the scientist or the person who develops science have a lot to say, but sometimes he thinks and people in his scientific community think that he is less of a scientist because he communicates science. (Alice, age 25-34, university education)

But others already know that scientists are currently required to develop outreach activities and see this as in a positive light

\begin{abstract}
I was going to say that I think it has to be really the scientists and not with intermediaries, because the scientists even now have a time that is for them... how they are evaluated, it's not, they have an evaluation of them, like us, they are evaluated, and there is a time when the scientists have to be in direct communication with people and that for people is very important and makes all the difference. (Júlia, age 45-54, university education)
\end{abstract}

Even though citizens talk much more about the presence of scientists in the media, a few participants have experienced other more face-to-face and interactive forms of science communication, such as PubhD (Ph.D. students presenting their thesis in bars), FameLab (a science communication competition where participants present a scientific topic in under three minutes), open days at research centres or lectures in schools. These initiatives are much appreciated by the public, as an opportunity to engage directly with scientists and meet them in their 'habitat' or in everyday life places.

In Braga there is really such a project to be disseminated through the university. They are university students who do the dissemination in which they invite people, citizens, in a certain place. Usually, it is a very informal place, such as a cafe, where they will discuss various areas and usually they are university students who make the presentation of various topics. (Madalena, age 45-54, university education)

This obligation can even go beyond communication of results and involve other stages of the research process, namely to carry out public interest research and work in close connection with affected communities, pressuring political power to solve critical problems like climate change

I think it is very important that scientists in various fields stop thinking only about publishing in order to have that value... and start developing science to effectively educate and work with society. I also think that it is not only doing the lectures and workshops at a theoretical level (...) communication should also involve a practical part, working with people... identifying in the case of climate change a population of a coastal zone (...) Adapt communication and work with these populations according to their realities. (Alice, age $25-34$, university education)

Conversely, not all participants agreed that scientists should communicate their research themselves. Some feel it falls outside of their role,

I do not feel that it is the role of scientists to communicate to my grandfather. It is not. (Marta, age 18-24, university education) 
others that they lack the necessary communication skills and yet no participant suggested that scientists should receive training in this field

It is not necessarily the author of the academic publication who should present it because there are people who are not at all good at making presentations and turn a good subject into a boring one. (Henrique, age 55-64, university education)

Some participants still see as scientists and academia as alien to society, who persist in using language that is too complex and have no regard for the needs and concerns of ordinary people

Another issue which is also important and which is upstream of all this is the ivory towers which are the universities, which is the academy, and which tend not to approach the citizens. In other words, people are very happy when they publish their paper in a reference institution with a high impact factor, but what does this mean for society? (Nuno, age 35-44, university education)

but can sometimes be understood as arrogance and scientists who are seen to despise their interlocutor do a disservice to communication

And I think they even look at it one way sometimes... Arrogant and laughing at people who do not understand them, that is, the fatal mistake on television, instead of taking a proactive attitude of going to correct in a positive way they are able after commenting "look at those donkeys, the journalists, who know nothing". (Ana, age 55-64, university education)

Participants are also critical of the communication role of scientists when they perceive that they speak outside their area of expertise

Even recently XXX, she is a researcher, for all intents and purposes she is a researcher, all right in the field of social sciences, and she had a perfectly unbelievable speech on television saying that there is no consensus [on climate change]. (Paulo, age 45-54, university education)

or motivated by interests other than science, such as economic or political, jeopardising their role as producers of knowledge

For scientists, for example, Monsanto obviously has renowned scientists doing articles, and we will find them on the Internet, but today companies also have the scientists who pay and who steer them towards particular aspects. So that is also complicated. (Mónica, age 45-54, university education)

Overall, the consultation shows that scientists are the most valued member of the science communication ecosystem. Citizens recognise them authority and credibility above all other actors. They cherish the opportunities to listen to them in the media but also to engage with them directly in events. However, the public also makes a critical assessment of science communication by scientists, awarding them different levels of credibility and acknowledging limits to their expertise, availability and communication skills. 
Despite Mejlgaard et al. [2012] positive statements on science journalism in countries with a consolidated science communication culture, the situation in Portugal has taken a turn for the worse in recent years. After government support to training abroad for science journalists in the 1990s, that yielded an increased coverage of science in the media, the 2000s saw a progressive decline in the number of specialised sections in media and in the number of science journalists [Entradas, Junqueira and Pinto, 2020]. This decline is undoubtedly connected to the significant changes legacy media worldwide is undergoing, with clear impacts on science journalism, but also specific conditions in Portugal. Printed newspapers are disappearing or getting thinner by the day, most are working with much reduced staff, TV news broadcasts are getting longer but paying less attention to science news (and more to live broadcasts, sports and entertainment) [Garcia et al., 2020]. There are no longer dedicated science programmes in non-subscription TV and despite high-penetration of cable TV (89\% of families in 2020) there are only available documentary-based international channels (Discovery, National Geographic).

It is thus predictable that participants in the consultation in Portugal, despite mentioning traditional media as the main channel for the science information they access to, show a less than enthusiastic reliance on journalists as a source of information. There is barely any mention of specialised science journalists (perhaps because they are few and participants are not able to identify them, except in one case), so all comments were made with journalists in general in mind.

Participants criticise journalists for being ill-informed about the issues they write about, compromising their ability to be impartial. They do not expect them to be specialised in the topics (there was no specific mention to science journalists) but rather to be able to familiarise himself or herself with it.

I think the media and journalism leave a lot to be desired. The journalists we have are not properly informed about the issues and when they make a news story it is always in a very partial way. Often very distorted, out of context... (...) there should be several journalists to be, not experts, but familiar in some areas. (Luísa, age 45-54, university education)

Some participants then suggested a solution: providing science training to journalists.

Science training for journalists is fundamental, not to mention mathematics. (...) For a journalist 10 million or 10 billion is exactly the same thing. (Ana, age 55-64, university education)

People diagnose a change in the professional ethos of journalists, driven by the pressure to deliver news and leading them to forego basic principles of journalism, such as verification of sources.

Today there is a lot of information that is not correct. There is a lot of journalism, in inverted commas, that is not done by journalists, because real journalism has to investigate the sources, it has to get to the bottom of the issues. And that is missing, there is no reliable information. (Bárbara, age 45-54, university education) 
Scientists are openly favoured above journalists in media

Normally, if it is an expert, I give more attention, if it is a journalist I give much less, because there it is, there are such economic interests behind it and I never know when the news comes out biased and therefore I tend to privilege experts and scientists.

(Odete, age over 65, university education)

However, there is also some criticism of scientists as well. By making themselves unavailable or by using complex language, scientists hinder the 'translation' work of journalists

Scientists lock themselves very much in their own cocoon. And now it is either their fault or it is the fault of those who do not look for them. Who are the journalists?

(Diogo, age 45-54, secondary education)

Participants talk about not just journalists but also the organisations for which they work (TV channels, newspapers), often as frames for science communication by journalists, advancing or hurdling their work through their agendas and the resources they make available for science news.

On the one hand, traditional media (in particular public TV channels and quality newspapers) is still seen as more trustworthy than new media or personal relations:

If it is traditional media, like the company... like RTP [public channel], passing on false information... may not even be. But it has more risk, it has an image to look out for, and it has more risk of falling into disrepute. (Vasco, age 18-24, secondary education)

But on the other hand, traditional media is seen as increasingly following the lead of digital media and foregoing their own agenda

I also get the idea and the feeling that the media go far behind what is flashy at the moment, what calls and jumps in the moment and go far in the wave of the [social] networks of what is viral, of what is spoken of (Tomás, age 25-34, university education)

There is also the perception that media outlets are business companies, with business interests, and that news are products to sell, which tends to undermine trust in the information they provide:

[about interests] media have behind them, there it is, economic groups, isn't it?! So, they are not exempt, very recently, if there is still completely independent and exempt media, isn't it?! (Ângela, age 45-54, university education)

And yet people recognise that good journalism requires financial resources:

asking people who are information editors (...) why there is no money to make time for quality information, and get people used to having quality information. (Tomás, age 25-34, university education) 
TV channels are criticised for privileging breaking news and not doing their research properly, misleading their audiences

channel wants to launch first hand... which also searches too fast and then searches in a very superficial way and from there it is already giving bad information to the citizen. (Madalena, age 45-54, university education)

Media are also criticised for having a short attention span, giving prominence to events but not to their follow-up.

\begin{abstract}
And here too there is a little bit, (...) the blame of the mass media, which at the time when the phenomena happen give extreme... value... and it has to be, all right. And you make a set of reports and so on and so forth and then as time goes by you get forgotten and then you do not really ask, then and now after 2 years, after 3 years, what has actually been done, what has not been done, what has changed, what has not changed (Salvador, age $35-44$, university education)
\end{abstract}

People still hang on to the conventional values that journalism should be impartial. But topics such as climate change, where there is scientific consensus, threw this value into disarray

Journalism must be impartial, it must have no agenda, it must have both sides. But journalism today is made, not to have both sides, with regard to climate change to the environment, but to be guided by a certain action... and a catastrophic vision is made (Tomás, age 25-34, university education)

And even though criticism of sensationalism still prevails, citizens admit exceptions when it is climate change that is at stake. If it helps raise awareness and convey the message to people who are unaware of high-brow discussions about scientific topics

I think they are fundamental, to reach a different audience. (...) I think the sensationalists reach... who maybe is less attentive to the subject... in themselves, but who then retain... that something is going on. (Adília, age 45-54, university education)

Conversely, also in climate change coverage, people ask for more in-depth information about the science behind it, rather than isolated, human interest details (for instance, loss of property in disaster situations).

Citizens at times reproduce the criticism scientists often point out at journalists, that their work is misread and misquoted:

It is very common, a problem that happens a lot of times: I read an article in the general press, I read the lead, and then I get the link to the scientific article, I open the scientific article and it says the opposite. It is not saying it right, it's saying the opposite. (Paulo, age 45-54, university education) 
Some citizens also want science news to follow the rules of scientific writing, by directly referencing the studies in which they are based, and identifying the authors and the funders

One of the things that goes with that idea you said is that journalists often write "this is based on a university study" and you have to click three times [to find it]. Probably what should happen is that instead of having to click three times, the link to that study should be included in the news. (Nuno, age 35-44, university education)

In sum, the consultation results show that science communication by journalism comes under heavy criticism from the public. Citizens seem to hark back to a golden time of journalism and find current practitioners and their practices lacking. Despite acknowledging that journalists and media are under significant constraints, they expect more from science coverage in terms of depth, accuracy and balance. Collaborations between scientists and journalists should be improved, for the sake of public good.

Regarding mediators other than journalists, in Portugal, as in other countries, a new occupation of professional science communicators has been emerging. This is a fairly diversified group of often former researchers (many with Ph.D.s in STEM) whose main task is to carry out science dissemination activities. These professionals have benefited from the growth of the science communication 'industry' in Portugal: from the late 1990's a network of close to 30 science centres has emerged, under the aegis of Agência Ciência Viva [Delicado, 2010]; university museums have been renovated or created anew [Lourenço and Dias, 2017]; most research centres now have science communication departments [Entradas and Bauer, 2017]; there are dozens civil society organisations solely dedicated to science communication [Conceição, 2021]. The professionals have gathered together in an association (SciComPT) funded in 2014 which holds annual conferences and provides training and a science journalism prize. The characterisation of this community is yet to be made, but it numbers around 400 members [Entradas, Junqueira and Pinto, 2020]. Training of science communication practitioners started in 2003 with a workshop in a research centre which had one of the first science communication departments in the country [Bettencourt-Dias, Godinho Coutinho and Araújo, 2004] and went on to be consolidated in postgraduate training (master degree courses, the first of which started in at the Nova University of Lisbon in 2011).

The results of the consultation show that citizens are not at all familiar with this new group of science communication professionals. First, older participants remember fondly science popularisers who used to appear on TV some decades ago, from diverse disciplines. Besides well-known international names (Carl Sagan, Jacques Costeau), they mention Portuguese ones as well (all men, all of advanced age, which goes to show who is still considered authoritative in the field).

Even though participants are mostly unaware of the existence of professional science communicators, some recognise the need for having specialised mediators who assist scientists in communication

This information exists, but is so complex, so I do not know if it is up to the scientist, who has a role here to produce knowledge if it is up to him to simplify and adapt it to a 
context. Maybe there are professions that should exist that do not exist yet, and I think that is what maybe... (...) Facilitators... of communication in science (Marta, age $18-24$, university education)

Citizens see a role for professional science communicators in media, not as science journalists but rather as 'translators', who make the bridge between science producers and the public thanks to a set of specific skills

I think there should be a new profession that is being debated in universities that is the role of translator, that is a person who... if we transmit the science directly to the consumer, first does he not read, is not palatable. But there is a translator's role that can pass on information, communicate science as it should be, but with accessible language, but without misleading the message [sic], which is what often happens. (Nádia, age 35-44, university education)

Citizens also consider that these mediators/translators are necessary in in governmental institutions, particularly those in the health sector

[they should] have health communicators, as there are for science, as there are science communicators who make it fun and get people to participate through group dynamics, get people involved in health since they are very young. (Marta, age 18-24, university education)

Overall, there is no public awareness of the existence of professional science communicators. They are probably mistaken for scientists in activities such as open days and only one or two people mentioned museums or science centres, one of the places where they would be more noticeable.

Finally, and although it is difficult to draw significant sociodemographic conclusions from an unrepresentative sample, there are some patterns among the participants that seem relevant to highlight. In terms of educational levels, scientists and journalists are more or less similarly mentioned in all groups except for the lower levels (secondary or less) in which journalists are more often mentioned than scientists. Science communicators in particular are cited almost exclusively by participants with tertiary education. As for age, older adults (over 65) almost did not refer to science communicators, which is the less relevant category in all age groups. Conversely, scientists are more cited in the 25-34 age group. This seems to indicate that the invisibility of professional science communicators is even greater among citizens with lower educational levels and in older age groups.

Conclusion

The public (represented here by the participants in our consultation) does pay attention to the actors of science communication. Who communicates science does matter, in particular when issues of trust are at stake.

Citizens place much more trust on the communication done by the producers of scientific knowledge than in the one done by mediators, such as journalists. They also trust more sources that are seen as disinterested, such as public universities, 
than sources with private interest, such as the media conglomerates behind TV channels and newspapers. The public calls for scientists in the media, but also for opportunities to engage with them directly, ask questions, see them at work, even collaborate with them in public interest research. The public's perceptions are aligned with Peters [2013] conclusion that most scientists consider collaboration with the media important and a matter of professional duty.

And yet, much like the perception scientists themselves in some cases have [Bucchi, 2008; Davies, 2008], a few of the participants were aware that scientists can be criticised and devalued by participating in science communication. And participants are also critical of the communication role of scientists when they perceive that they speak outside their area of expertise, a risk already highlighted by Peters [2014].

Format matters too. When scientists fail to deliver communication in a clear language and with practical implications, citizens would rather have skilled mediators doing the translation. Curiously, no participant suggested that scientists should receive training in communicating skills, unlike what the literature advocates [Besley and Tanner, 2011; Trench and Miller, 2012; Baram-Tsabari and Lewenstein, 2017].

Citizens understand that mediators, in particular journalists, experience significant pressure to conform to norms that are very different from the scientific field, even when covering science. But, much like what Peters et al. [2008] found in a survey of scientists, some citizens also want science news to follow the rules of scientific writing, by directly referencing the studies in which they are based, and identifying the authors and the funders. Citizens at times reproduce the criticism scientists often point out at journalists [Dunwoody, 2014], that their work is misread and misquoted. People still uphold conventional values that journalism should be impartial, but topics such as climate change, where 'balance is bias' [Boykoff and Boykoff, 2004; Dunwoody, 2014] has led them to adopt more nuanced views.

The public is also mostly aware of the significant changes legacy media worldwide is undergoing, with clear impacts on the journalistic coverage of scientific issues [Pinholster and O'Malley, 2006; Granado, 2011; Bauer, Howard et al., 2013]. Nevertheless, TV channels are criticised for privileging breaking news and not doing their research properly (much like what Granado [2011] had found in the survey of science journalists), misleading their audiences. Media are also criticised for having a short attention span, giving prominence to events but not to their follow-up. However, as Dunwoody [2014, p. 32] points out, science journalism, like other kinds of journalism is episodic by nature, based on 'shorter stories about concrete happenings than longer, thematic stories about issues'. Some participants then suggested a solution that is also common of debates in the field [Dunwoody, 2004]: providing science training to journalists.

Finally, the issue of invisibility. Scientists and journalists are figures firmly established in popular representations. Lab coats and notebooks or microphones are signifiers of professional identities that are easily recognisable. The new professional communicators are not so easy to distinguish. They work mostly in the background, preparing exhibitions, managing institutional social media accounts, organising events, writing press releases. This invisibility may be compounded by 
the fact that most science communication professionals are women [Crettaz von Roten, 2011; Delicado, 2017; Lewenstein, 2019; Rasekoala, 2019], much like women scientists are still significantly overlooked in science communication [Fogg-Rogers and Hobbs, 2019]. Incipient signs of professionalisation, such as having specialised training or a professional organisation, are not visible to the audiences of science. And yet citizens recognise the need for their work. In a world where a cacophony of voices disputes the limelight of the public sphere, perhaps professional communicators of science may have an important role to play in battling scientific disinformation and misinformation.

Overall, more work needs to be done on the public perceptions of science communication and science communicators. If we are to cater for the needs and concerns of audiences of science communication, we must understand what those needs and concerns are. If we are to foster public trust in the knowledge that science produces, we need to identify the most effective ways to communicate that knowledge. A first step would be to make use of the data produced in the CONCISE project and explore comparisons between countries, in order to understand how different ecosystems of science communication influence the public perception about its actors. A second step should be to going beyond small and unrepresentative samples of motivated participants and scale-up the analyses, through national or European surveys, to assess just how widespread and varied are the trends we identified.

\section{References}

AbiGhannam, N. (2016). 'Madam Science Communicator: a typology of women's experiences in online science communication'. Science Communication 38 (4), pp. 468-494. https://doi.org/10.1177/1075547016655545.

Baram-Tsabari, A. and Lewenstein, B. V. (2017). 'Preparing scientists to be science communicators'. In: Preparing informal science educators. Ed. by P. Patrick. Cham, Switzerland: Springer, pp. 437-471. https://doi.org/10.1007/978-3-319-50398-1_22.

Bauer, M. W., Howard, S., Romo Ramos, Y. J., Massarani, L. and Amorim, L. (2013). Global science journalism report: working conditions $\mathcal{E}$ practices, professional ethos and future expectations. Our Learning Series. London, U.K.: Science and Development Network.

Bauer, M. W. and Jensen, P. (2011). 'The mobilization of scientists for public engagement'. Public Understanding of Science 20 (1), pp. 3-11. https://doi.org/10.1177/0963662510394457.

Besley, J. C. and Tanner, A. H. (2011). 'What science communication scholars think about training scientists to communicate'. Science Communication 33 (2), pp. 239-263. https://doi.org/10.1177/1075547010386972.

Bettencourt-Dias, M., Godinho Coutinho, A. and Araújo, S. J. (2004). 'Strategies to promote science communication: organisation and evaluation of a workshop to improve the communication between Portuguese researchers, the media and the public'. Comunicação e Sociedade 6, pp. 89-112. https://doi.org/10.17231/comsoc.6(2004).1230.

Boykoff, M. T. and Boykoff, J. M. (2004). 'Balance as bias: global warming and the US prestige press'. Global Environmental Change 14 (2), pp. 125-136. https://doi.org/10.1016/j.gloenvcha.2003.10.001. 
Bucchi, M. (2008). 'Of deficits, deviations and dialogues: theories of public communication of science'. In: Handbook of public communication of science and technology. Ed. by M. Bucchi and B. Trench. London, U.K. and New York, U.S.A.: Routledge, pp. 57-76.

Carvalho, A. and Pereira, E. (2008). 'Communicating climate change in Portugal: a critical analysis of journalism and beyond'. In: Communicating climate change: discourses, mediations and perceptions. Ed. by A. Carvalho. Braga, Portugal: Centro de Estudos de Comunicação e Sociedade (CECS), Universidade do Minho, pp. 126-156.

Cerrato, S., Daelli, V., Pertot, H. and Puccioni, O. (2018). 'The public-engaged scientists: motivations, enablers and barriers'. Research for All 2 (2), pp. 313-322. https://doi.org/10.18546/RFA.02.2.09.

Conceição, C. P. (2021). 'Bringing science to public: is it still a matter for scientific associations?' In: Communicating science and technology in society: issues of public accountability and engagement. Ed. by A. Delicado, F. Crettaz von Roten and K. Prpić. Cham, Switzerland: Springer, pp. 97-116. https://doi.org/10.1007/978-3-030-52885-0_6.

Crettaz von Roten, F. (2011). 'Gender differences in scientists' public outreach and engagement activities'. Science Communication 33 (1), pp. 52-75. https://doi.org/10.1177/1075547010378658.

Davies, S. R. (2008). 'Constructing communication: talking to scientists about talking to the public'. Science Communication 29 (4), pp. 413-434. https://doi.org/10.1177/1075547008316222.

Delicado, A. (2010). 'Exhibiting science in Portugal: practices and representations in museums'. Portuguese Journal of Social Science 9 (1), pp. 19-32. https://doi.org/10.1386/pjss.9.1.19_1.

- (2017). 'Women in science communication'. In: Encyclopedia of international higher education systems and institutions. Ed. by P. Teixeira and J. C. Shin. Dordrecht, The Netherlands: Springer. https://doi.org/10.1007/978-94-017-9553-1_354-1.

Dudo, A. and Besley, J. C. (2016). 'Scientists' prioritization of communication objectives for public engagement'. PLoS ONE 11 (2), e0148867. https://doi.org/10.1371/journal.pone.0148867.

Dunwoody, S. (2004). 'How valuable is formal science training to science journalists?' Comunicação e Sociedade 6, pp. 75-87. https://doi.org/10.17231/comsoc.6(2004).1229.

- (2014). 'Science journalism: prospects in the digital age'. In: Routledge handbook of public communication of science and technology. Ed. by M. Bucchi and B. Trench. 2nd ed. London, U.K. and New York, U.S.A.: Routledge, pp. 27-39. https://doi .org/10.4324/9780203483794.

Entradas, M. and Bauer, M. M. (2017). 'Mobilisation for public engagement: benchmarking the practices of research institutes'. Public Understanding of Science 26 (7), pp. 771-788. https : //doi .org/10.1177/0963662516633834.

Entradas, M., Junqueira, L. and Pinto, B. (2020). 'Portugal. The late bloom of (modern) science communication'. In: Communicating science: a global perspective. Ed. by T. Gascoigne, B. Schiele, J. Leach, M. Riedlinger, B. V. Lewenstein, L. Massarani and P. Broks. Canberra, ACT, Australia: Australian National University Press, pp. 693-714. https://doi.org/10.22459/CS.2020.29. 
Fogg-Rogers, L. and Hobbs, L. (2019). 'Catch 22 - Improving visibility of women in science and engineering for both recruitment and retention'. JCOM 18 (04), C05. https://doi.org/10.22323/2.18040305.

Garcia, J. L., Martinho, T. D., da Cunha, D. S., Alves, M. P., Matos, J. and Graça, S. M., eds. (2020). O choque tecno-liberal, os media e o jornalismo: estudos críticos sobre a realidade portuguesa. Lisbon, Portugal: Edições Almedina.

Gascoigne, T. and Metcalfe, J. (1997). 'Incentives and impediments to scientists communicating through the media'. Science Communication 18 (3), pp. 265-282. https://doi.org/10.1177/1075547097018003005.

- (2017). 'The emergence of modern science communication in Australia'. JCOM 16 (03), A01. https://doi .org/10.22323/2.16030201.

Granado, A. (2011). 'Slaves to journals, serfs to the web: the use of the Internet in newsgathering among European science journalists'. Journalism 12 (7), pp. 794-813. https://doi .org/10.1177/1464884911412702.

Horst, M. (2013). 'A field of expertise, the organization, or science itself? Scientists' perception of representing research in public communication'. Science Communication 35 (6), pp. 758-779. https://doi.org/10.1177/1075547013487513.

Jensen, E. and Holliman, R. (2016). 'Norms and values in UK science engagement practice'. International Journal of Science Education, Part B 6 (1), pp. 68-88. https://doi.org/10.1080/21548455.2014.995743.

King, N. and Brooks, J. (2018). 'Thematic analysis in organisational research'. In: The SAGE handbook of qualitative business and management research methods: methods and challenges. Ed. by C. Cassell, A. L. Cunliffe and G. Grandy. Thousand Oaks, CA, U.S.A.: SAGE Publications, pp. 219-236. https://doi.org/10.4135/9781526430236.

Lewenstein, B. (2019). 'The need for feminist approaches to science communication'. JCOM 18 (04), C01. https ://doi .org/10.22323/2 . 18040301.

Longnecker, N. and Gondwe, M. (2014). 'Graduate degree programmes in science communication: educating and training science communicators to work with communities'. In: Communicating science to the public: opportunities and challenges for the Asia-Pacific region. Ed. by L. T. W. Hin and R. Subramaniam. Dordrecht, The Netherlands: Springer, pp. 141-160. https://doi.org/10.1007/978-94-017-9097-0_9.

Lourenço, M. C. and Dias, J. P. S. (2017). “Time capsules” of science: museums, collections, and scientific heritage in Portugal'. Isis 108 (2), pp. 390-398. https://doi.org/10.1086/692690.

Martín-Sempere, M. J., Garzón-García, B. and Rey-Rocha, J. (2008). 'Scientists' motivation to communicate science and technology to the public: surveying participants at the Madrid Science Fair'. Public Understanding of Science 17 (3), pp. 349-367. https://doi.org/10.1177/0963662506067660.

Mejlgaard, N., Bloch, C., Degn, L., Nielsen, M. W. and Ravn, T. (2012). 'Locating science in society across Europe: clusters and consequences'. Science and Public Policy 39 (6), pp. 741-750. https: //doi.org/10.1093/scipol/scs092.

Mizumachi, E., Matsuda, K., Kano, K., Kawakami, M. and Kato, K. (2011). 'Scientists' attitudes toward a dialogue with the public: a study using "science cafes"'. JCOM 10 (04), A02. https://doi.org/10.22323/2.10040202. 
Neresini, F. and Bucchi, M. (2011). 'Which indicators for the new public engagement activities? An exploratory study of European research institutions'. Public Understanding of Science 20 (1), pp. 64-79. https://doi.org/10.1177/0963662510388363.

Nielsen, K. H. (2010). 'More than "mountain guides" of science: a questionnaire survey of professional science communicators in Denmark'. JCOM 09 (02), A02. https://doi.org/10.22323/2.09020202.

Nielsen, K. H., Kjaer, C. R. and Dahlgaard, J. (2007). 'Scientists and science communication: a Danish survey'. JCOM 06 (01), A01. https://doi.org/10.22323/2.06010201.

Peters, H. P. (2013). 'Gap between science and media revisited: scientists as public communicators'. Proceedings of the National Academy of Sciences 110 (Supplement 3), pp. 14102-14109. https://doi.org/10.1073/pnas.1212745110.

- (2014). 'Scientists as public experts: expectations and responsibilities'. In: Routledge handbook of public communication of science and technology. Ed. by M. Bucchi and B. Trench. 2nd ed. London, U.K. and New York, U.S.A.: Routledge, pp. 70-82. https://doi.org/10.4324/9780203483794.

Peters, H. P., Heinrichs, H., Jung, A., Kallfass, M. and Petersen, I. (2008). 'Medialization of science as a prerequisite of its legitimization and political relevance'. In: Communicating science in social contexts. New models, new practices. Ed. by D. Cheng, M. Claessens, T. Gascoigne, J. Metcalfe, B. Schiele and S. Shi. Dordrecht, The Netherlands: Springer, pp. 71-92. https://doi.org/10.1007/978-1-4020-8598-7_5.

Pinholster, G. and O'Malley, C. (2006). 'EurekAlert! Survey confirms challenges for science communicators in the post-print era'. JCOM 05 (03), C01. https://doi.org/10.22323/2.05030301.

Pinto, B. M. L., Costa, J. L. and Cabral, H. N. (2017). 'How do science communication practitioners view scientists and audiences in relation to public engagement activities? A research note concerning the marine sciences in Portugal'. Bulletin of Science, Technology \& Society 37 (3), pp. 159-166. https://doi.org/10.1177/0270467618819683.

Poliakoff, E. and Webb, T. L. (2007). 'What factors predict scientists' intentions to participate in public engagement of science activities?' Science Communication 29 (2), pp. 242-263. https://doi.org/10.1177/1075547007308009.

Rasekoala, E. (2019). 'The seeming paradox of the need for a feminist agenda for science communication and the notion of science communication as a 'ghetto' of women's over-representation: perspectives, interrogations and nuances from the global south'. JCOM 18 (04), C07. https: //doi.org/10.22323/2.18040307.

Ridgway, A., Milani, E., Weitkamp, E. and Wilkinson, C. (2019). Scoping report on the science communication ecosystem. https://doi .org/10.5281/zenodo.3607151.

Riesch, H., Potter, C. and Davies, L. (2016). 'What is public engagement, and what is it for? A study of scientists' and science communicators' views'. Bulletin of Science, Technology \& Society 36 (3), pp. 179-189. https://doi.org/10.1177/0270467617690057.

Sánchez-Mora, C., Reynoso-Haynes, E., Sánchez Mora, A. M. and Tagüeña Parga, J. (2015). 'Public communication of science in Mexico: past, present and future of a profession'. Public Understanding of Science 24 (1), pp. 38-52.

https://doi.org/10.1177/0963662514527204. 
Trench, B. (2017a). 'The rocky road of science communication in Ireland'. In: Little Country, Big Talk - Science communication in Ireland. Ed. by B. Trench, P. Murphy and D. Fahy. Luton, U.K.: Celsius, Dublin \& Pantaneto Press.

- (2017b). 'Universities, science communication and professionalism'. JCOM 16 (05), C02. https://doi.org/10.22323/2.16050302.

Trench, B. and Miller, S. (2012). 'Policies and practices in supporting scientists' public communication through training'. Science and Public Policy 39 (6), pp. 722-731. https://doi.org/10.1093/scipol/scs090.

Authors

Ana Delicado is a Research Fellow at the Instituto de Ciências Sociais da Universidade de Lisboa. She specialises in social studies of science and technology. E-mail: ana.delicado@ics.ulisboa.pt.

Jussara Rowland is a Research Assistant at the Instituto de Ciências Sociais da Universidade de Lisboa and a Ph.D. candidate.

E-mail: jussara.rowland@ics.ulisboa.pt.

João Estevens is a political scientist and economist. He is now finishing his Ph.D. in Global Studies. Research assistant at ICS-ULisbon and researcher at the Portuguese Institute of International Relations-NOVA University of Lisbon (Democracy and Governance). His interests include state punitiveness, democracy, security studies, migration, and science communication. E-mail: joao.estevens@ics.ulisboa.pt.

How to cite

Delicado, A., Rowland, J. and Estevens, J. (2021). 'Bringing back the debate on mediated and unmediated science communication: the public's perspective'. JCOM 20 (03), A10. https:/ / doi.org/10.22323/2.20030210. 